\title{
Stakeholders Influence on Successful Business Succession
}

\author{
A. Chamaru De Alwis ${ }^{1}$ \\ ${ }^{1}$ Faculty of Commerce and Management Studies, University of Kelaniya, Sri Lanka \\ Correspondence: A. Chamaru De Alwis, Senior Lecturer Grade 1, Faculty of Commerce and Management Studies, \\ University of Kelaniya, Sri Lanka.
}

Received: June 28, 2016

Accepted: July 10, 2016

Online Published: July 17, 2016

doi:10.5430/ijba.v7n4p79

URL: http://dx.doi.org/10.5430/ijba.v7n4p79

\begin{abstract}
Family owned Bushiness face one extremely vital issue with their generational business succession due to poor performance the business succession process brings short-term life to the entire unit. A number of studies suggest conducting empirical research to find causes behind this issue; however this vicinity is lack with an integrated framework for empirical investigations. Here, Author has used stakeholder theory to build model by conducting an exploratory study for systematically examine the empirical and theoretical literature. Then, by extrapolating, interpolating, and making logical connections among those, that exploratory study has developed the conceptual framework and the hypotheses to measure the relative importance of different influences come from stakeholders in this critical process.
\end{abstract}

Keywords: business succession, family, incumbent, successor, satisfaction, post succession performance

\section{Background of the Study}

Family- Owned Businesses (FOBs) dominate the current world economy in particular eras in the past but also at present (Morck and Yeung, 2004). The current degree of business performance, though, is somewhat different. Current FOBs have problems sustaining their business. The reality is of course that FOBs are currently struggling with their problem of inheriting their business. In other words, they are struggling for long-term survival after a new Chief Executive Officer (CEO) succeeded the business (Chung and Liu, 2007).

In recent history, FOBs have increasingly been considered concerning policy decisions (Mandl, 2008), because they greatly contribute to economic and social development (Mandl, 2008). FOBs are actually the predominant form of business organization, and play a vital role in today's Capitalistic economy and social well-being. Beckhard and Dyer (1983) estimated the number of FOBs worldwide, and confirm that about $65 \%$ to $90 \%$ of all businesses in various nations continue to develop this sector. According to Malhotra (2010), $80 \%$ of all businesses worldwide are family businesses. In Europe, more than $75 \%$ of all businesses are family owned. They contribute greatly to Gross National Production (GDP) in most nations and are quite proudly the main employment provider. Because of these conditions, FOBs have become the dominant sector in the Capitalistic economy.

However, FOBs face one extremely vital issue with their generational business succession. According to Ward (1987) and Kets de Vries (1993), "only 30\% of FOBs survive into the second generation, and $15 \%$ survive into the third generation." Miller \& Steier, (2003) explain that poor Business Succession Process (BSP) is the central reason for this. This scenario has not only affected particular organizations, but has also directly affected the national economy due to lack of contribution.

FOB stakeholders influence this succession process in various ways. The incumbent successor and family are the main stakeholders of the business succession process (Handler, 1989b). In the BSP, the incumbent leaves their position and gives their business handling authority to someone else. Sometimes, this will affect their recognition, and some are not happy to give up their position. Sometimes, they may think handing over power will cause future business problems. Under these circumstances, the incumbent refuses to withdraw from the business. If they have built the business themselves, it makes it more difficult to leave the position. Even after employing a successor who is a non-family manager, the owner may tend to influence the decision making phase. The successor is the one taking responsibility to lead the organization into a successful future. Now everyone's eyes are focused toward them, as they run the business and try fulfilling stakeholders' expectations. The challenges running the business for the successor are somewhat complex, especially when family members have different expectations for what they must 
do for the FOB. For instance, some family members may be directly involved with the FOB, and some not. However, all of them may have hidden or open expectations of goals for the FOB. The worst situation happens when the successor cannot accomplish those expectations from other family members, and then family members will go against the BSP as well as the successor. This most probably is experienced by successors who are outsiders. Therefore, the rapport of both parties of their commitment, trust and agreement to work is very important for a successful BSP.

\section{Main Objective of This Paper}

As explained previously, BSPs of FOBs have become a serious issue for the longevity of this business entity. Therefore, there is a high tendency among researchers and practitioners to find feasible solutions to this succession issue, however no one has researched stakeholder influences under the same conditions with well integrated framework. This paper aims to develop a conceptual framework understanding of this phenomenon, described in the previous section.

\section{Conceptual Framework}

This paper used the "stakeholder theory of the firm" as the grounded theory. This conceptual framework has identified stakeholder's related factors of the BSP as the independent variables and the post-succession business performance and initial satisfaction with the business succession process as dependent variables of the study.

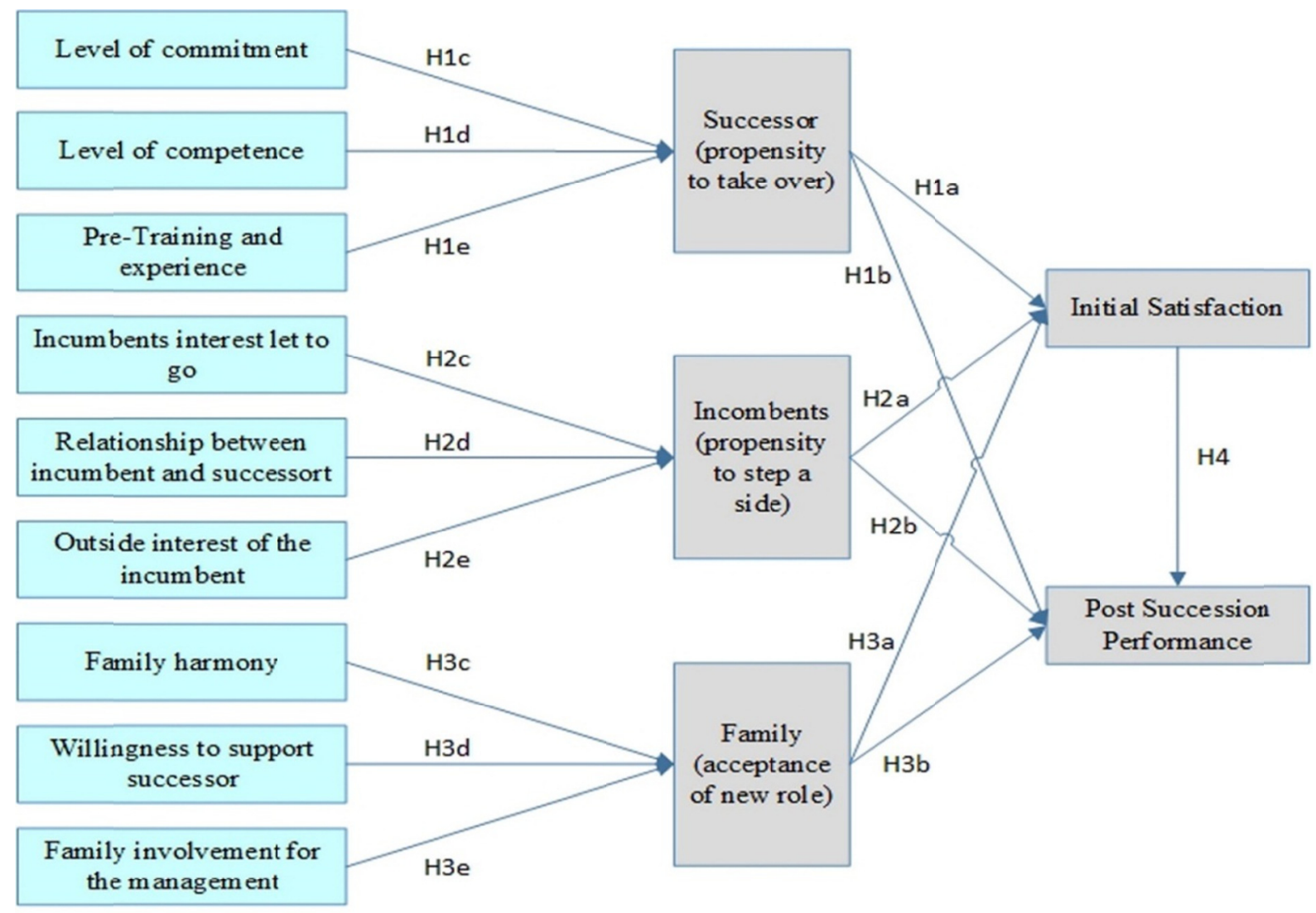

Figure 1. Couceptual framework

Source: Designed by the author based on literature 


\section{Variables}

This study identified 11 independent variables that can influence the BSP, and two dependent variables; initial statistician with business succession process and post-succession business performance of the FOB. Moreover, there are two control variables for the study: family-member successor and unrelated manager successor.

\subsection{Success of the Business Succession Process}

There is no definite agreement among researchers about what contributes to the successfulness or effectiveness of BSP in FOB. Some researchers suggest "satisfaction of the BSP from the incumbent, the successor and other family members, as the indicator of the Perceived success" (Cabrera-Suárez et al., 2001; Dyer, 1986). However, those researchers have considered only one side of the BSP, which is the main stakeholders' (the incumbent, the successor and other family members') satisfaction with the BSP. Apart from that, others have used "successors' ability to keep the FOB healthy" as the measurement to appraise the business unit. Venter et al. (2005) and Sharma and Irving (2005) express the perceived success of the BSP is determined by the extent of satisfaction with the process and continued profitability. Handler (1989a) and Morris Williams, Allen, Avila. (1997) also mention that "success has two interactive dimensions: satisfaction with the process and the effectiveness of succession." Chrisman et al. (2005) express the importance of family relations and the effectiveness of the business entity, and they identified two perspectives to measure the success of the process: business performance and family harmony, and named these as "two pillars for family firm performance." The researcher agrees with Cabrera-Suarez, De Saa-perez, Garcia-almeida (2001) ; Dyer (1986); Handler (1990); Morris et al. (1997); Sharma, Chrisman, Pablo, Chua,(2001) and they believe that the success of the BSP is defined as "the subsequent positive performance of the firm, the ultimate viability of the business and the satisfaction of stakeholders with the succession process." At last, a conceptual argument can be brought toward as an interactive relationship between these two dimensions of success in the BSP of FOB. According to Sharma et al. (2001) “...performance may also alter family member's satisfaction with the succession process even in the absence of any changes in the relationships among family members."

The level of influence coming from stakeholder-related factors and influencing business succession was evaluated. "Stakeholders are any group or individual who can affect or is affected by the achievement of the firm's objectives" (Freeman, 1984). According to this theory, the importance of a particular stakeholder in influencing the direction, decisions, and actions of the firm depends on that stakeholder's stake, power, legitimacy and urgency (Freeman, 1984). Incumbent, successor and family who has the ownership of the FOB recognized as "the stakeholders of the BSP" according to Handler's (1989a) classification.

\subsection{Successor (Factors Influencing the Propensity to Take over the Business)}

H1 a: Successors propensity to take over the position has a positive relationship with stakeholder's initial satisfaction with business succession process

H1b: Successors propensity to take over the position has a positive relationship with post succession performances

\subsubsection{Level of Commitment of the Successor}

A successor's true commitment and willingness are direct influences on the success of the BSP (Chrisman Chua, Sharma, 1998). If a successor refuses to take over the new position, it automatically stops the entire process. This can happen due to them having other opportunities with higher benefits. In addition to this, there can be a poor relationship with the incumbent or with the family, or lack of self-confidence might be another common reason that decreases the commitment level of the successor. Successions are much more successful when the candidate-successor has a strong desire to lead the family business and finds this a fascinating challenge. Goldberg and Wooldridge (1993) define commitment as "the successor's willingness to take over the business" and it is considered to be a crucial factor in the success of succession in family firms (Chrisman et al., 1998). A strong commitment results when offspring want to join the company, feel appreciated and profoundly welcome, are not forced by parents to be executives or successors, and can choose whether or not to join the family firm (Barach and Ganitsky, 1995).

H1c: Level of commitment of the successor has a positive relationship with successor's propensity to take over the position

\subsubsection{Level of the Competence of the Successor}

The successor's interest to be a successor in itself is not sufficient. They should also be a very competent person, who can perform their duties at the expected competency level because this level of competency directly affects the current and future performance and the survival of the business in today's competitive, dynamic, drastically changing 
environment (Barach and Gantisky, 1995). According to Dun and Bradstreet (1972), 45\% percent of all businesses fail due to the inappropriate appointing of successors. Some appointed managers are not competent enough to hold management positions; they may not be ready to be in the strategic decision table. Usually they themselves refuse to accept the position after identifying their incompetency. Sometimes, that refusal can be raised from the family or from the incumbent, if they lack confidence in the successor. The central theme of the succession process is that the FOB

Management ends in the hands of a very competent and well-motivated successor (Matser and Lievens, n.d.). According to Chrisman et al. (1998), the following characteristics are deemed vital for candidate-successors: "integrity, commitment to the family business, ability to command respect from the personnel, decisiveness and interpersonal skills." Some authors identify the characteristics of management skills as the competence of the successor. According to past literature, one point can be easily understood. Each and every researcher has explained at least one part of the competencies of the successor in order to be a successful replacement. Yet few have given attention to developing the structure of such competence. Porvaznik and Coll (2008) have developed a new way of thinking to fulfil this void in their book, "Holistic Management, Pillars of Competence in Management".

H1d: Level of competence of the successor has a positive relationship with successor's propensity to take over the position

\subsubsection{Pre-training and Experience}

The training the successor receives, either internally or externally, might have positive influences on a successful BSP. Ward (1987) discovers that the successor's development for the leadership role is one of the most important factors for survival after BSP. Internal business training brings early exposure to the organization, opportunities to become familiar with the internal settings and opportunities to work with the existing managers and workforce, and to develop capabilities need by the firm (Ward, 1987). Simultaneously, if they have external experience, this will help successors work with self-confidence (Dyer, 1986). Not only training, but pre-development planning is also needed at this point. This study defines level of pre-training and experience as the "How much respect the successor gains from piers due to knowledge and familiarity with their position within a short period of time"

H1e: Pre-training and experience of the successor have a positive relationship with successor's propensity to take over the position

\subsection{The Incumbent (Factors Influencing the Propensity of the Incumbent to Step Aside)}

To measure the level of influence coming from the incumbent on a successful BSP, three factors were measured: the "incumbent's interest step aside from the position, the relationship between the incumbent and the successor and outside interests of the successor."

H2a: Incumbents propensity to step aside has a positive relationship with successor's initial satisfaction with the business succession process

$\mathrm{H} 2 \mathrm{~b}$ : Incumbents propensity to step aside has a positive relationship with post succession performances

\subsubsection{The Incumbent's Interest Let to Go}

Through reviewing past literature, Sharma et al. (2001); Davis (1982) and Handler (1989a) all disclosed that the "business owner's inability of letting go is the most cited obstacle to effective succession." If the incumbent is not happy to step aside, that badly affects the entire BSP (Dyck, Mauws, Starke, Mischke, 2002; Sharma, Chrisman, Chua, 2003; Dascher and Jens, 1999; and Sharma et al., 2001, 2003). According to Sharma (2001) "incumbent's tendency to go out highly depends on the initial satisfaction with the business succession process, the level of relationship with the successor, and his confidence about his future protection." If he does not have much propensity to step aside, it appears as though they are against the successor's freedom to make decisions and strategic implementations. Therefore, "leave him go to attend to his interest" can be identified as one influential factor of a successful BSP.

H2c: Incumbents interest let to go has a positive relationship with Incumbents propensity to step aside

\subsubsection{The Relationship between the Incumbent and Successor}

The level of the relationship built up between successor and incumbent is another factor that affects the BSP. Family-member successors might have better opportunities to build up close relationships with other family members than non-relative successors. If they have a good relationship it might have a good influence on the overall succession process. If the incumbent has a great share of ownership of the company after the transition of the 
leadership to another (family member or non-family manager), there is a great possibility to supervise the new successor very closely. That creates a principal-agent relationship between the incumbent and the successor.

$\mathrm{H} 2 \mathrm{~d}$ : Relationship between incumbent and the successor has a positive relationship with Incumbents propensity to step aside

4.3.3 Outside Interests of the Incumbent

According to Sharma (2001), "the urgency of the incumbent to initiate succession will partially depend upon whether he or she has interests outside the business." Therefore, if he or she has an interest in stepping aside, authorized personnel should consider this a matter of fact situation and let him or her leave the position without letting him or her interrupt the BSP. This study defines outside interest of the incumbents as "The level of benefits given to the incumbent after his steps- down from management and the outside activities that the incumbent is involved with at the time succession takes place." Therefore, in this study, was measured this factor from two perspectives: "amount of outside activities" "reorganization gained through outside activities"

H2e: Outside interest of the incumbent has a positive relationship with Incumbents propensity to step aside

\subsection{Family (Factors Influencing Acceptance of the New Role)}

The family can be identified as the next influential stakeholder group of the BSP (Chrisman et al., 1998; and Sharma and Rao, 2000) and if they act against the BSP, it will block the entire process of the BSP (De Massis Chua, Chrisman., 2008; Lansberg, 1983).

H3a: Acceptance of the new role of family members has a positive relationship with successor's initial satisfaction with the business succession process

H3b: Acceptance of the new role of family members has a positive relationship with post succession performances

\subsubsection{Family Harmony}

The factors carrying a high level of influence on the BSP include family members' commitments to the business (Dyck et al., 2002); their trust in the successor's capabilities (Dyck et al., 2002; Sharma, 1997; Sharma et al., 2001); and their mutual agreement to accept the new successor and continue the business (Sharma et al., 2003). Churchill and Hatten (1987); Dyer (1986); Handler (1990) all identified the combination of these qualities as increasing family harmony, and this generates a shared vision for every participant (Sharma et al., 2001).

H3c: Family harmony has a positive relationship with acceptance of new roles by family members

\subsubsection{Willingness to Support the Successor}

According to Tagiuri and Davis (1992), "an overlapping and interdependent relationship can be seen between the FOB, the owners of the business, and the family that controls the business." If family members are not committed to the succession, it blocks the opportunity to demonstrate the requisite management abilities of the successor (De Massis et al., 2008). Moreover, most frequently, family members are more willing to offer higher positions to their relatives than to outsiders. In addition, they should be very willing to share their knowledge and portfolio of professional capabilities with relatives. However, in some instances, family members that hold important roles in the company may threaten to leave the company because of dissatisfaction with the selection.

H3c: Willingness to support the successor has a positive relationship with acceptance of new roles by family members

\subsubsection{Family Involvement in Management}

Generally, the director of the board of any type of company is consisted the owners of the entity. It is not dissimilar with FOBs, and based on the level of ownership, family-members take positions on the board of directors. If the business is totally owned by one company, on most occasions, the entire board is represented solely by family members. If a high percentage of family-members are in executive positions, they have the power of decision making. In other words, without interference, they can decide the future direction of the company.

H3c: Family involvement in management has a positive relationship with acceptance of new roles by family members

\subsection{Relationship between Initial with Business Succession Process and Post Succession Business Performance}

If the successor is not pleased with the process done by the FOB to appoint him and especially with the different influences come from stakeholders, there is a chance it to influence to his way of acting as a Chief Executive officer. Therefore, finally, this model proposes to measure the relationship between successor's initial satisfaction with the 
business succession process and post succession performance.

H4: There is a positive relationship between successors initial satisfaction with the business succession process and post succession performance.

\section{Discussions}

There is a bulk of literature on various issues relevant to business succession in FOBs (Handler, 1994 and Wortman, 1994). This is due to poor performance the BSP brings short-term life to the entire unit (Handler, 1994). This poor result affects the business entity and eventually also the national economy. Therefore, business succession processes have become a fundamental topic of FOB research (Sharma, Chrisman, and Chua, 1996). Researchers have given attention to different factors influencing the BSP such as:

The incumbent (Ambrose, 1983; Handler, 1990, and 1992; Morris et al., 1997; Dascher and Jens, 1999; Dyck et al., 2002; Sharma et al., 2003a), the successor (Barach, Gantisky, Carson, Doochin., 1988; Morris et al., 1997; Handler, 1990; Chrisman et al, 1998; Dascher and Jens, 1999; Sharma, Chua, Chrisman., 2000; Sharma at al., 2003), the family (Handler, 1990; Morris et al., 1997; Dyck et al., 2002) and the other stakeholders (Steier, 2001).

Pyromalis and Rogdaki (2004) analyzed past literature and mentioned the lack of an integrated conceptual framework dealing with both dimensions of post-succession performance of FOBs; the initial satisfaction and effectiveness of the business succession process. The conceptual framework developed by Morris et al. (1997) focuses on the effectiveness of succession. Pyromalis and Rogdaki (2004) developed a conceptual framework by considering a two- dimensional approach, but it did not address all independent variables in a proper manner. Furthermore, no one has combined those post succession performance indicators with stakeholder related influential factors in one framework to identify the relative importance of these influential factors. Additionally, most of the studies were done without a proper theoretical background (Sharma et al., 2003b) and many of the published articles are simply based on casual observations rather than well designed empirical studies (Brockhaus, 2004). Thus, Handler (1989a) suggested developing an advanced research design and the use of statistical tools to expand the literature in this field. This paper addressed that established issues through a well-developed conceptual framework.

\section{Conclusions}

This paper has attempted to develop a conceptual framework to evaluate how stakeholders influence to the successors initial satisfaction with the business succession process and his post succession performance. Further, it will help to measure the relationship between two depended variables: initial satisfaction with the business succession process and successors post succession business performances. This model has been developed with existing findings from the literature. It can form the basis for empirical studies of what determine successor's initial satisfaction with the succession process and post succession performance. By identifying the factors that influence the succession process, this model will help stakeholders in the business succession process of the FOB to manage their influence to get maximum benefits from the entity. In addition to that this will help to recognize the relative importance of the factors and help Managers decide which factors deserve the most attention when planning for and managing the succession process in their firms.

\section{References}

Ambrose, D. M. (1983). Transfer of the family owned business. Journal of Small Business Management, 21(1), 49-56.

Barach, J. A., \& Gantisky, J. (1995). Successful succession in family business. J. of Family Business Review, 8(20), 131-155. http://dx.doi.org/10.1111/j.1741-6248.1995.00131.x

Barach, J. A., Gantisky, J., Carson, J.A., \& Doochin, B.A. (1988). Entry of the next generation: Strategic challenge for family business. Journal of Small Business Management, 269(2), 49-56.

Beckhard, R., \& Dyer, W. G., JR. (1983). SMR Forum: Managing Change in the Family Firm: Issues and Strategies. Sloan Management Review, 24(3), 59-65.

Brockhaus, R.H. (2004). Family Business Succession: Suggestions for Future Research. Family Business Review. http://dx.doi.org/10.1111/j.1741-6248.2004.00011.x

Cabrera-suarez, K., De Saa-perez, E, \& Garcia-almeida, D. (2001). The succession process from a resource and knowledge-based view of the family firm. $J$. of Family Business Review, l14(1), 37-47. http://dx.doi.org/10.1111/j.1741-6248.2001.00037.x

Chrisman, J. J., Chua, J. H., \& Sharma, P. (1998). Important attributes of successors in family businesses: An 
exploratory study. Journal of Family Business Review, 11(1), 19-34. http://dx.doi.org/10.1111/j.1741-6248.1998.00019.x

Chrisman, J. J., Chua, J. H., \& Sharma, P. (2005). Trends and Directions in the Development of a Strategic Management Theory of the Family Firm. Journal Entrepreneurship Theory and Practice, 29(5), 555-576. http://dx.doi.org/10.1111/j.1540-6520.2005.00098.x

Chung, H. M., \& Liu, Y. S. (2007). The Business of Taiwan's Succession in Family Business. Retrieved from http://www.isb.edu/FamilyBusinessConferencepdf

Churchill, N. C., \& Hatten, K. J. (1987). Non-market based transfers of wealth and power: A research framework for family businesses. American J. of Small Business, 12, 53-66.

Dascher, Jens, W. (1999). Family business succession planning. J. of Business Horizons, 42(5), 2-4. http://dx.doi.org/10.1016/S0007-6813(99)80068-8

Davis, J. A. (1982). The influence of life-stage on father-son work relationship in family companies. Doctoral Dissertation, Dascher. Retrieved from http://onlinelibrary.wiley.com/doi/10.1111/j.1741-6248.1989.00047.x/pdf

De Massis, A., Chua, J. H., \& Chrisman, J. J. (2008). Factors preventing intra-family succession. J. of Family Business Review, 21(2), 183-199. http://dx.doi.org/10.1111/j.1741-6248.2008.00118.x

Dun, B. (1972). The Failure Record through 1971. New York: Business Economics Department,

Dyck, B., Mauws, M., Starke, F. A., \& Mischke, G. A. (2002). Passing the baton: The importance of sequence, timing, technique and communication in executive succession. Journal of Business Venturing, 17(2) 143-162. http://dx.doi.org/10.1016/S0883-9026(00)00056-2

Dyer, W. G. JR. (1986). Cultural change in family firms: Anticipating and managing business and family transitions. San Francisco: Jossey-Bass. A, E,

Freeman, R. E. (1984). Strategic Management: A stakeholder Approach. Boston, MA: Pitman. Retrieved from http://papers.ssrn.com/sol3/papers.cfm?

Goldberg, S. D., \& Wooldridge, B. (1993). Self-confidence and managerial autonomy: Successor characteristics critical to succession in family firms. Journal of Family Business Review, 6, 55-73. http://dx.doi.org/10.1111/j.1741-6248.1993.00055.x

Handler, W. C. (1989a). Methodological issues and considerations in studying family businesses. Journal of Family Business Review, 26(2), 49-56. http://dx.doi.org/10.1111/j.1741-6248.1989.00257.x

Handler, W. C. (1989b). Managing the family firm succession process: The next generation family member's expedience. Doctoral dissertation School of Management, Boston Universit. Retrieved from http://www.uk.sagep ub.com/chaston/20chapters\%201-12/Chapter\%2011\%20-\%2014

Handler, W. C. (1990). Succession in family firms: A mutual role adjustment between entrepreneur and next-generation family members. Journal of Entrepreneurship Theory and Practice, 15(1), 37-51.

Handler, W. C. (1992). Succession experience of the next generation, Journal of Family Business Review, 5(3), 283-307. http://dx.doi.org/10.1111/j.1741-6248.1992.00283.x

Handler, W. C. (1994). Succession in family businesses: A review of the research. Journal of Family Business Review, 7(2), 133-157. http://dx.doi.org/10.1111/j.1741-6248.1994.00133.x

Kets De Vries, M. F. R. (1993). The dynamics of family controlled firms: The good and the bad news. Journal of Organizational Dynamics. http://dx.doi.org/10.1016/0090-2616(93)90071-8

Lansberg, I. S. (1983). Resources in Family Firms: The Problem of Institutional Overlap. Journal of Organizational Dynamics, 12(1), 39-46. http://dx.doi.org/10.1016/0090-2616(83)90025-6

Malhotra, H. B. (2010). Family Businesses and the Global Economy. The Epoch Times. Retrieved from http://www.theepochtimes.com/n2/content/view/35702

Mandl, I. (2008). Overview of Family Business Relevant Issues Contract No. 30-CE- 0164021/00-51, Final Report Mandl 2008 Retrieved from http://eceuropa.eu/enterprise/policies/sme/files/craft/familybusiness/doc/familybusinessstudyn.pdfp.175

Matser, I., \& Lievens, J. (n.d) Succession the scorecard assist family a tool to business's trans-generational continuity. Retrieved

from 
http://www.ownershiptransfer2010.org/wp-ntent/uploads/2010/03/TransefOwnership2010_IlMatser.pdf

Miller, D., Steier, L., \& Le Breton-miner, I. (2003). Lost in time: Intergenerational succession, change and failure in family. Journal of Business Venturing, 18(4), 513-531. http://dx.doi.org/10.1016/S0883-9026(03)00058-2

Morck, R., \& Yeung, B. (2004). Family Control and Rent-Seeking Society. Journal of Entrepreneurship Theory and Practice, 38(1), 79-92. http://dx.doi.org/10.1111/j.1540-6520.2004.00053.x

Morris, M. H., Williams, R. O., Allen, J. A., \& Avila, R. A. (1997). Correlates of success in family business transitions. J. of Business Venturing, 12(5), 385-401. http://dx.doi.org/10.1016/S0883-9026(97)00010-4

Porvazník, J. C. (2008). Holistic Management: pillars of competence in Management. Bratislava: IRIS, p. 447.

Sharma, P. (2001) Stakeholder management concepts in family firms. Proceedings of International Association of Business and Society [IABS],

Sharma, P., Chrisman, J. J., \& Chua, J. H. (1996). A review and annotated bibliography of family business studies. Kluwer Academic Publishers: Boston, MA.

Sharma, P., Chrisman, J. J., \& Chua, J. H. (2003a). Predictors of satisfaction with the succession process in family firms. J. of Business Venturing, 18(5). http://dx.doi.org/10.1016/S0883-9026(03)00015-6

Sharma, P., Chrisman, J. J., Pablo, A. L., \& Chua, J. H. (2001). Determinants of initial satisfaction business succession process in Family Firms: A Conceptual Model. J. of Entrepreneurship Theory and Practice, 26(2), 17-35.

Sharma, P., Chrisman, J.J., \& Chua, J.H. (2003). Succession planning as planned behaviour: Some Empirical Results. J. of Family Business Review, 37(4), 42-58.

Sharma, P., Chua, J.H., \& Chrisman, J.J. (2000). Perceptions about the extent of succession planning in Canadian family firms. Canadian Journal of Administrative Sciences, 17(3), 233-244. http://dx.doi.org/10.1111/j.1936-4490.2000.tb00223.x

Sharma, P., \& Irving, P.G. (2005). Four Bases of Family Business Successor Commitment: Antecedents and Consequences. Entrepreneurship. Journal of Theory and Practice, 29(1), 13-33. http://dx.doi.org/10.1111/j.1540-6520.2005.00067.x

Steier, L. (2001). Next-Generation entrepreneurs and Succession: An Exploratory Study of Modes and Means of Managing Social Capital. Journal of Family Business Review, 14(3), 259-276. http://dx.doi.org/10.1111/j.1741-6248.2001.00259.x

Tagiuri, R., \& Davis, J.A. (1992, March). On the Goals of Successful Family Companies. J. of Family Business Review, 5(1), 43-62. http://dx.doi.org/10.1111/j.1741-6248.1992.00043.x

Venter, E., Boshoff, C., \& Maas, G. (2005). Succession in family businesses in South Africa: a comparative study of owner-managers and successors, Dascher. Retrieved from http:// sbae r.ua. edu/research/icsb/2004/paper7.pdf

Ward, J. L. (1987). Keeping the family business healthy: How to plan for continuing growth, profitability, and family leadership. San Francisco: Jossey-Bass. A, E, p.255.

Wortman, JR., M. S. (1994). Theoretical foundations for family owned businesses: A conceptual and research based paradigm. Journal of Family Business Review, 7(1), 3-27.

Yromalis, V. D., \& Rogdaki, M.E. (2004). An integrated framework for testing the success of the family Business Succession process according to gender specificity. Retrieved from http://www.sbaer.uca.edu/Research/al 